\title{
ANALISIS UPAYA PENEMUAN KASUS HIV AIDS DI RSUD KRATON KABUPATEN PEKALONGAN
}

\author{
Ida Baroroh ${ }^{1}$, Millatin Puspaningtyas ${ }^{2}$, Dian Kusumawardani ${ }^{3}$, Putri Andanawarih ${ }^{4}$ \\ Email : idamidoren@gmail.com \\ ${ }^{1234}$ Akademi Kebidanan Harapan Ibu Pekalongan, Jl. Sriwijaya No. 7 Kota Pekalongan. \\ Telp 085102998866
}

\begin{abstract}
Abstrak
HIV/AIDS merupakan penyakit menular seksual yang dapat menular seluruh lapisan masyarakat. Jumlah penderita HIV/AIDS di Kabupaten Pekalongan meningkat signifikan sepanjang tahun 2013 yaitu mencapai 26 orang. Salah satu upaya penanggulangan HIV/AIDS adalah dengan deteksi dini yang dilakukan secara sukarela, bukan dipaksa atau diwajibkan untuk mengetahui status HIV lebih dini dengan pemanfaatan layanan-layanan terkait dalam pencegahan, perawatan, dukungan dan pengobatan sehingga konseling dan testing HIV/AIDS dapat berjalan. Tujuan penelitian ini adalah melakukan analisis upaya penemuan kasus HIV/AIDS di RSUD Kraton Kabupaten Pekalongan.

Metode penelitian ini adalah kualitatif, dengan Informan utama terdiri dari 2 orang konselor PICT dan Informan triangulasi yaitu Kepala PICT, kepala bidang pelayanan kesehatan dan kepala bidang keperawatan RSUD Kraton Kabupaten Pekalongan. Pengumpulan data melalui wawancara mendalam serta analisis dengan content-analysis.

Hasil penelitian menunjukkan bahwa upaya penemuan kasus HIV/AIDS dilihat dari aspek individu yaitu ketrampilan yang dimiliki provider sudah cukup mendukung. Dari aspek organisasi yaitu kepemimpinan sudah baik, namun untuk sumber daya dan imbalan masih terbatas jumlahnya dan struktur organisasi belum dapat berjalan sesuai dengan tupoksi. Aspek Psikologi meliputi sikap provider sudah cukup baik dalam penemuan kasus HIV/AIDS berdasarkan pengalaman selama menjalankan program, sedangkan motivasi muncul dari dalam diri konselor sendiri sebagai wujud professionalisme dalam menjalankan tugas.

Disarankan untuk dilakukan supervisi secara berkala oleh Dinas Kesehatan Kabupaten Pekalongan dalam memantau kegiatan PICT, dan bagi RSUD Kraton Kabupaten Pekalonganuntuk dapat menyediakan klinik VCT sesuaidengan standaryang telah ditentukan.
\end{abstract}

Kata Kunci: HIV, AIDS, Upaya Penemuan Kasus

\section{Pendahuluan}

Acquired Immune Deficiency Syndrome (AIDS) memang telah menjadi epidemi yang sangat serius mengancam kesehatan masyarakat dunia. Angka Internasional menunjukkan lebih dari 14.000 infeksi baru terjadi setiap hari dan diperkirakan 40,3 juta orang hidup dengan status HIV/AIDS di dunia pada tahun 2005. Menurut Organisasi Kesehatan Dunia (WHO), seorang penderita HIV/AIDS berpotensi menulari sekitar 200 orang lainnya. Kasus HIV/AIDS di Indonesia sejak pertama kali ditemukan yaitu pada tahun 1987 sampai Juni 2012 terdapat 30.103 kasus AIDS dan 86.762 terinfeksi HIV di 33 propinsi di Indonesia [16].

Presentase komulatif AIDS tertinggi pada umur 20-29 tahun (41,5\%), kemudian diikuti kelompok umur 30-39 tahun
(30,8\%), 40-49 tahun (11,6\%), 15-19 tahun (4,1\%), dan 50-59 tahun (3,7\%). Rasio kasus AIDS antara laki-laki dan perempuan adalah 2:1 ( laki - laki 70\% dan perempuan $29 \%$ ). Presentase faktor resiko AIDS tertinggi adalah hubungan seks tidak aman pada heteroseksual $(84,5 \%)$, pengguna jarum suntik tidak steril pada penasun (6\%), dari ibu positiv HIV ke anak (3,9\%), Lelaki Seks Lelaki (3,9\%) (Ditjen PP \& PL Kemenkes RI, 2012) $)^{[4]}$.

AIDS (Acquired Immunodeficiency Syndrome) merupakan kumpulan sindrom akibat adanya infeksi HIV (Human Immunodeficiency Virus) yang menyerang sel sistem kekebalan tubuh manusia sehingga kekebalan tubuh penderita AIDS menurun secara progresif, sehingga mudah diserang berbagai penyakit penyerta seperti pneumonia, tuberkulosis, meningitis, 
karposki sarkoma, serta penyakit lainnya yang dapat membahayakan hidup penderita AIDS. Penularan HIV dapat dengan mudah terjadi melalui kontak langsung antar membran mukosa atau darah dengan cairan tubuh yang terpapar virus dan dapat melemahkan kekebalan tubuh penderita, serta fakta bahwa saat ini belum ada obat yang efektif menyembuhkan, sehingga HIV/AIDS masih merupakan "momok" bagi dunia kesehatan dunia saat ini.

Rekapitulasi penderita HIV/AIDS di Kabupaten Pekalongan pada tahun 20052012 yang ditemukan sebanyak 36 penderita dari total 75 penderita. Tahun 2013 ditemukan 26 penderita HIV. Oleh karena begitu besarnya dampak yang diakibatkan oleh HIV/ AIDS, pengendalian HIV dan AIDS, malaria, dan penyakit menular lainnya menjadi poin keenam dalam Millenium Development Goals (MDG's) yang harus dicapai setiap negara pada tahun 2015. Oleh karena itu, masalah - masalah dalam penanggulangan HIV AIDS ini harus segera diatasi.

Salah satu program yang dilaksanakan pemerintah untuk mencegah penularan HIV/AIDS adalah melalui Provider Initiated Counseling and Testing (PICT). Provider Initiated Counseling and Testing (PICT) HIV merupakan program deteksi dini HIV/AIDS. Deteksi dini ini dalam upaya mengendalikan penyebaran virus HIV/AIDS. Deteksi dini dapat mencegah penderita HIV yang tidak tahu bahwa dirinya terinfeksi untuk tidak menularkan HIV kepada orang lain karena penderita HIV sudah berpotensi untuk menularkan virus HIV kepada orang lain meskipun belum menunjukkan gejala klinis. Selain itu, dengan adanya deteksi dini, penderita HIV/AIDS dapat menjalani terapi obat antiretroviral (ARV) sedini mungkin karena pengobatan sejak dini dapat meningkatkan efektivitas pengobatan HIV/AIDS dan meningkatkan harapan hidup penderita.

Indonesia dan sebagian besar negara lain, telah mengadakan program konseling dan test HIV sukarela atau VCT. Program VCT dilakukan secara sukarela dan rahasia. Namun, karena sifatnya sukarela, VCT belum dapat berjalan maksimal. Masyarakat belum secara sukarela penuh untuk melakukan VCT karena minimnya pengetahuan dan stigma masyarakat, serta perasaan malu dan takut. Hal ini tentu saja diperparah dengan suatu fakta bahwa gejala gejala penyakit akibat infeksi HIV baru muncul setelah beberapa tahun terinfeksi virus HIV, sehingga para penderita HIV tidak merasa sakit yang berakibat menambah keengganan mereka untuk melakukan VCT.

Sebuah penelitian di Los Angeles dan New York mengenai program VCT dan PICT, menyatakan bahwa manfaat PICT yang jauh lebih baik. Jika pengobatan dengan cara VCT merupakan inisiatif awal dari klien, maka pada tes rutin inisiatif awal untuk tes HIV dari petugas kesehatan disebut PICT. Pada periode yang sama, VCT dapat menjaring 1.500 pasein sedangkan PICT dapat menjaring 31.000 pasien. Tes rutin mengidentifikasi HIV positif, 4 kali lebih banyak dan prevalensi yang konsisten pada program PICT.

Program PICT ini memiliki daya jangkau lebih luas dari VCT karena inisiatif tes berasal dari petugas kesehatan sehingga mampu menghindari keterlambatan diagnosis. Peran provider kesehatan dalam PICT lebih efektif karena merupakan penentu pelaksanaan program ini.

Provider kesehatan berperan aktif untuk melihat pasien bersangkutan memiliki gejala-gejala terinfeksi HIV maupun faktor risiko tinggi terpapar HIV atau tidak sehingga deteksi dini HIV dapat lebih efektif. Penderita penyakit yang memiliki kemungkinan menderita HIV/ AIDS adalah penderita penyakit infeksi menular seksual (IMS), tuberculosis, dan beberapa penyakit lainnya. PICT juga sebagai salah satu asuhan keperawatan sebelum melahirkan karena meningkatnya Mother to Child Transmission (MTCT) pada beberapa tahun terakhir.

Program PICT hanya memberikan alternatif "opt-out" form, dimana pasien berhak menolak melakukan tes HIV. Konsultasi sebelum tes (pre-test counseling) tidak ada dalam PICT, namun hanya ada konsultasi setelah tes (post-test counseling) sehingga keputusan untuk pemeriksaan HIV dapat lebih cepat dilakukan. Hal ini 
dikarenakan hak asasi pasien merupakan hal utama dalam melaksanakan program ini.

Berdasarkan latar belakang tersebut peneliti tertarik melakukan penelitian dengan judul "Analisis Upaya Penemuan Kasus HIV/AIDS di RSUD Kraton Kabupaten Pekalongan".

\section{Metode Penelitian}

Jenis penelitian adalah analitik kualitatif yang disajikan secara deskriptif melalui observasi dan wawancara mendalam dengan suatu kuesioner terstruktur. Metode kualitatif digunakan peneliti untuk mendapatkan pemahaman tentang upaya petugas kesehatan dalam penemuan kasus HIV/AIDS di RSUD Kraton Kabupaten Pekalongan. Wawancara mendalam dilakukan terhadap informan utama yaitu 2 orang konselor PICT RSUD Kraton Kabupaten Pekalongan, dan informan triangulasi antara lain Kepala Klinik PICT, Kabid Pelayanan Kesehatan RSUD Kraton Kabupaten Pekalongan, Kasie Pelayanan Kesehatan RSUD Kraton Kabupaten Pekalongan, dan Kabid Keperawatan RSUD Kraton Kabupaten Pekalongan. Data sekunder diperoleh melalui pengamatan dengan melihat faktorfaktor yang meliputi sarana prasana, sumberdaya, cara pendekatan kepada kelompok beresiko, dan kinerja petugas hingga menjaring kasus HIV/AIDS.

\section{Hasil dan Pembahasan}

Upaya penemuan kasus HIV/AIDS di RSUD Kraton Kabupaten Pekalongan dilakukan dengan melalui PICT (Provider Initiated Counseling and Testing) yang sudah berjalan selama kurang lebih 10 tahun. Penelitian dilakukan terhadap 3 variabel, yang meliputi variabel individu (ketrampilan dan demografi), variabel psikologis (sikap dan motivasi), dan variabel organisasi (kepemimpinan, sumber daya, imbalan dan struktur).

A. Variabel Individu

\section{1) Ketrampilan}

Hasil penelitian yang dilakukan menunjukkan bahwa ketrampilan konselor yang terdiri dari perawat dan dokter yang ada di RSUD Kraton sudah cukup baik karena semua konselor sudah mengikuti pelatihan. Namun untuk konselor yang lebih terampil dan lebih aktif dalam PICT hanya 1 orang, sedangkan 1 konselor lainnya jarang memberikan konseling karena kesibukan jadwal dinas ruangan. Hal ini yang menyebabkan pelayanan konseling HIV/AIDS kurang maksimal dilakukan.

Hasil penelitian ini sesuai dengan istilah yang diungkapkan oleh Dessler, Gary (2007) bahwa pelatihan (training) mengacu pada serangkaian kegiatan yang memberikan peluang untuk mendapatkan dan meningkatkan keterampilan yang berkaitan dengan pekerjaan. Program pelatihan diberikan kepada karyawan yang baru maupun karyawan yang telah ada, tujuannya adalah untuk menghadapi situasi -situasi yang berubah. Sementara itu program pengembangan (development) dimaksudkan untuk mengembangkan keterampilan untuk pekerjaan masa depan. Pengembangan merupakan suatu proses pendidikan jangka panjang yang mempergunakan prosedur sistematis dan terorganisir dimana karyawan manajerial mempelajari pengetahuan konseptual dan teoritis guna mencapai tujuan umum.

2) Demografi

Berdasarkan hasil wawancara mendalam baik dengan informan utama maupun informan triangulasi menunjukkan bahwa tenaga konselor yang selama ini terlibat langsung dalam pelaksanaan kegiatan PICT berusia kisaran antara 40-52 tahun dengan rata-rata usia informan 48 tahun dengan tingkat pendidikan Sarjana yaitu perawat dan dokter, sehingga menunjukkan bahwa petugas konselor sudah terlatih dan memenuhi persyaratan sebagai provider dalam PICT.

Sebagaimana diungkapkan dalam teori WHO (2007), PICT bertujuan untuk mengidentifikasi infeksi HIV terhadap klien yang tidak dikenali dan tidak dicurigai datang ke pelayanan kesehatan. Tes dan konseling HIV disarankan oleh penyelenggara pelayanan kesehatan sebagai bagian dari pelayanan yang diberikan kepada seluruh pasien selama interaksi-interaksi klinis yang dilakukan di pelayanan kesehatan ${ }^{[13] .}$. 
Dalam mekanisme PICT, peran provider kesehatan lebih efektif. perawat berperan aktif untuk melihat pasien bersangkutan memiliki gejala penyakit HIV, dengan melihat faktor risiko tinggi terpapar HIV. Atas dasar itu dokter dan perawat berhak memberi konseling dan rujukan agar pasien melakukan pemeriksaan lanjutan di laboratorium atau klinik HIV. Oleh karena itu, laju penyebaran HIV lebih mudah diketahui dengan menggunakan PICT.

Provider Initiated Counseling and HIV Testing (PICT) yang ada di RSUD Kraton sesuai dengan pedoman yang disahkan oleh WHO dan UNAIDS dimana tes HIV dan konseling direkomendasi oleh petugas kesehatan pada pasien yang berada di fasilitas kesehatan yang memenuhi komponen standar pelayanan kesehatan (Suwarto, 1999).

B. Variabel Psikologis

1) Sikap

Sikap konselor dalam upaya menemukan kasus HIV/AIDS berdasarkan pernyataan informan utama menyatakan bahwa pelaksanaannya melaui PICT. VCT-nya hanya jika ada pasien dengan kasus positif, selanjutnya orang-orang terdekatnya yang berpotensi yang dijadikan target konseling, tetapi awalnya dari PICT. Hal tersebut diperkuat dengan jawaban informan triangulasi yang mengungkapkan selama ini kasus HIV/AIDS yang ditemukan di RSUD Kraton dilakukan dengan PICT dimana pasien dilakukan konseling jika pasien rawat inap ditemukan tanda gejala penyakit penyerta HIV/AIDS misalnya diare kronis, sariawan, TBC.

Dapat disimpulkan sikap yang ditunjukkan oleh provider juga merupakan hasil pengalaman selama menjalankan program PICT. Hal ini sesuai dengan pengertian sikap menurut Robbins dimana pernyataan evaluatif baik yang menguntungkan atau tidak menguntungkan mengenai obyek, orang atau peristiwa. Sikap mencerminkan bagaimana seseorang merasakan sesuatu. Sikap diorganisasi melalui pengalaman dan menimbulkan pengaruh tertentu terhadap perilaku seseorang (Robbins, 2001).

\section{2) Motivasi}

Berkaitan dengan motivasi, dukungan yang diberikan rekan kerja dalam menemukan kasus HIV/AIDS, jawaban informan utama menyatakan dukungan dari rekan kerja 1 bangsal yang baik maupun kerjasama dalam melakukan skrining tanda gejala HIV AIDS merupakan motivasi yang mendukung proses pelayanan PICT di RSUD Kraton. Jawaban informan di atas diperkuat dengan ungkapan salah satu informan bahwa mereka memberikan konseling dalam PICT dikarenakan rasa empati terhadap para ODHA dan OHIDHA atau keluarga terdekatnya.

Adanya ketertarikan dalam menghadapi masalah banyak orang, ketertarikan dalam berkomunikasi dengan banyak orang, belajar menjadi pendengar yang baik terhadap permasalahan orang, belajar membangun relasi, dan menumbuhkan rasa empati. Ingin memberikan pemahaman kepada semua orang bahwa HIV sama dengan penyakit lainnya dan lambat laun akan menghilangkan stigma dan diskriminasi di masyarakat maupun di lingkungan rumah sakit.

Faktor pendorong untuk tetap memberikan PICT merupakan kunci dari motivasi yang ada dalam diri konselor dalam melaksanakan tugasnya, jawaban dari informan utama menyatakan bahwa rasa empati terhadap para ODHA maupun OHIDA yang mendorong para konselor untuk tetap memberikan PICT kepada pasien, selain karena tanggungjawab tugas sebagai konselor PICT.

Kesimpulan jawaban informan berkaitan juga dengan rasa tanggung jawab karena ditunjuk oleh atasan menjadi tim PICT yang merupakan bentuk penghargaan atasan terhadap petugas konselor. Atasan memberikan keyakinan bahwa bergabung menjadi tim PICT merupakan kesempatan yang baik untuk peduli terhadap sesama manusia dan menambah pengalaman dalam karier.

C. Variabel Organisasi

1) Kepemimpinan 
Berkaitan dengan kepemimpinan, kepala PICT dalam perannya sebagai pemimpin dan penanggungjawab dari pelaksanaan PICT di RSUD Kraton sangat mendukung dalam pelaksanaan kegiatan PICT. Namun, dalam pelaksanaannya kepala PICT hanya ikut terlibat apabila pasien dengan HIV AIDS sudah termasuk kategori berat diberikan konseling kepada istri ataupun keluarganya.

2) Sumber Daya

Berkaitan dengan sumber daya manusia bahwa jumlah petugas PICT ada 3 orang yaitu, 1 kepala PICT dan 2 konselor. Petugas konselor ini juga merangkap sebagai perawat di ruang bangsal, sehingga perlu dilakukan penambahan kuantitas rekan kerja. Karena akan banyak pasien yang terjaring setelah dilakukan penawaran tes HIV kepada pasien yang dicurigai terinfeksi HIV dengan tanda/gejala atau dari hasil anamnesa dan harus menjalankan peran ganda selama ini yaitu sebagai petugas konselor PICT dan petugas bangsal.

Menurut Green (1991) faktor enabling merupakan salah satu behavior causes dimana memungkinkan keinginan terlaksana mencakup sumber daya manusia untuk melakukan perilaku kesehatan. Pendapat Green senada dengan hasil wawancara dimana sebagian besar subyek dalam penelitian ini sudah merasa melakukan perannya di tim PICT dengan baik yaitu sebagai kepala dan konselor ${ }^{[6]}$.

Sumber dana dalam pelaksanaan kegiatan PICT di RSUD Kraton Kabupaten Pekalongan berasal dari Dinas Kesehatan Kabupaten Pekalongan berupa reagen untuk tes HIV di laboratorium sentral RSUD Kraton dan dana operasional rumah sakit. Sedangkan honorarium untuk petugas konselor tidak ada, kegiatan konseling dilakukan dengan sukarela karena tanggungjawab menjalankan tugas. Peralatan yang dibutuhkan dalam pelaksanaan kegiatan PICT hanya reagen untuk tes HIV saja.

3) Imbalan

Selama PICT berlangsung, tidak ada imbalan apapun bagi konselor maupun kepala PICT. Seluruh kegiatan dilakukan oleh provider atas dasar sukarela dan semata-mata karena rasa empati.

Hasil penelitian tersebut kurang sesuai dengan pendapat Azrul Azwar (1998) [3] bahwa memberikan kompensasi/imbalan sangat diperlukan sehingga pekerja mau dan bersedia melaksanakan segala perintah dengan baik. Didukung juga oleh pendapat Stainer (2004) bahwa uang masih tetap merupakan motivator paling penting, untuk itu perusahaan dituntut untuk dapat menetapkan kebijakan imbalan/kompensasi yang paling tepat, agar kinerja karyawan dapat terus ditingkatkan sekaligus untuk mencapai tujuan dari perusahaan.

Penghasilan yang dikenal dengan Imbalan/kompensasi yang menjadi hak setiap karyawan, menjadi faktor yang sangat penting dalam kehidupan individu, sebagaimana pendapat para psikolog yang menyatakan bahwa individu mempunyai banyak kebutuhan, tetapi hanya sebagian yang dapat secara langsung dipuaskan dengan uang, sedangkan kebutuhan lainnya dapat dipuaskan secara tidak langsung dengan uang. Berdasarkan Peraturan Pemerintah No. 3 Tahun 1996, imbalan mencakup semua pengeluaran yang dikeluarkan oleh perusahaan untuk pegawainya dan diterima atau dinikmati oleh pekerja baik secara langsung, rutin atau tidak langsung.

4) Struktur

Terkait dengan penyusunan atau pembentukan struktur organisasi kerja dalam PICT diperoleh informasi dari 2 informan utama menyatakan bahwa sudah ada struktur organisasi PICT dengan dikeluarkannya surat keputusan dari Direktur RSUD Kraton mengenai kepala dan tenaga konselor PICT. Namun karena belum memiliki ruangan khusus, sehingga struktur tersebut belum diberlakukan sebagaimana mestinya.

Proses pembagian tugas dalam menemukan kasus HIV/AIDS, dua informan utama dan tiga informan triangulasi menyampaikan bahwa pembagian tugas sudah disesuaikan dengan tupoksi masing-masing. Namun dalam pelaksanaannya, konselor tidak selalu melaporkan secara tertulis hasil 
temuan suspect HIV, konselor hanya melaporkan kasus secara lisan dan tatap muka. Hal ini dikarenakan konselor masih merangkap tugas sebagai kepala ruang di bangsal.

Jawaban informan tentang proses pelaporan hasil sama halnya dengan yang dikemukakan oleh Sutarto (1993) bahwa pelaporan tanggung jawab dari bawahan kepada atasannya juga dapat dilakukan melalui garis vertikal yang terpendek. Perintah-perintah hanya diberikan seorang atasan saja dan pelaporan tanggung jawab kepada atasan bersangkutan. Dalam hal ini, kegiatan PICT termasuk dalam organisasi lini yang merupakan suatu bentuk organisasi didalamnya terdapat garis wewenang yang menghubungkan langsung secara vertikal antara atasan dengan bawahan. Setiap petugas yang menjalankan tugasnya sesuai dengan bidang keahliannya masing-masing tentunya akan sangat paham dengan apa saja yang harus dilakukan, sehingga setiap apa yang disampaikan oleh konselor diharapkan selalu benar.

Pernyataan jawaban informan artinya bahwa struktur organisasi PICT sudah ada dan sudah tertulis di dalam surat keputusan Direktur Rumah sakit, namun dalam pelaksanaan tugas belum sepenuhnya merata di masing-masing bagian. Hal ini kurang sependapat dengan Robbins dan Coulter (2007) yang menyatakan struktur organisasi seharusnya sebagai kerangka kerja formal organisasi yang dengan kerangka kerja itu tugastugas pekerjaan dibagi-bagi, dikelompokkan, dan dikoordinasikan. Struktur organisasi memberikan pengaruh besar terhadap kepuasan dan kinerja karyawan.

\section{Simpulan}

a. Ketrampilan melakukan PICT yang dilakukan oleh konselor cukup baik karena didukung dengan mengikuti pelatihan.

b. Tenaga konselor yang selama ini terlibat langsung dalam pelaksanaan kegiatan PICT berusia kisaran antara 40-52 tahun dengan rata-rata usia informan 48 tahun dengan tingkat pendidikan Sarjana yaitu perawat dan dokter, sehingga menunjukkan bahwa petugas konselor sudah terlatih dan memenuhi persyaratan sebagai provider dalam PICT

c. Kegiatan PICT dilakukan hanya jika ada pasien dengan kasus positif, selanjutnya orang-orang terdekatnya yang berpotensi yang dijadikan target konseling.

d. Motivasi merupakan bentuk dari rasa tanggung jawab karena ditunjuk oleh atasan menjadi tim PICT yang merupakan bentuk penghargaan atasan terhadap petugas konselor. Atasan memberikan keyakinan bahwa bergabung menjadi tim PICT merupakan kesempatan yang baik untuk peduli terhadap sesama manusia dan menambah pengalaman dalam berkarier.

e. Sumber daya dalam kegiatan PICT terdiri dari jumlah petugas PICT, dana kegiatan dan peralatan yang dibutuhkan. Jumlah tenaga konselor masih sangat kurang karena hanya ada 2 konselor, tidak sumber dana kegiatan PICT, sedangkan peralatan yang digunakan hanya reagen yang diberikan oleh Dinas Kesehatan Kabupaten Pekalongan untuk tes HIV.

\section{Daftar Pustaka}

[1] Arikunto S. (2006). Prosedur penelitian suatu pendekatan praktek. Jakarta : Rineka Cipta

[2] Atom. 2009. Jenis-jenis Pemeriksaan HIV. Akses internet di http://www.wartamedika.com/2008/ 06/jenis-jenis-pemeriksaanhivaids.html, 1 Agustus 2009.

[3] Azrul Azwar, 1998. Menjaga Mutu Pelayanan Kesehatan. Jakarta. Pustaka Sinar Harapan.

[4] Depkes R.I Modul Pelatihan Konseling dan Tes Sukarela HIV (Voluntary Counselling and Testing). Jakarta : Dirjen P2M dan Penyehatan Lingkungan. 2004.

[5] Farmasia. 2007. Diagnosis Laboratorik Infeksi HIV. Akses internet di http://www.majalah- 
farmacia.com/rubrik/one_news.asp? IDNews=418, 3 Agustus 2009.

[6] Green, Lawrence. W. (1991). Health Promotion Planning and Educational and Eviroment approach. Mayfield. Publising Company New Toronto, London.

[7] Handoko, Rudi. 2007. HIV/AIDS Semakin Menakutkan?. Akses internet di http://kingroodee.blogspot.com/200 7/08/hiv-aids-semakin menakutkan.html, 1 Agustus 2009.

[8] Komisi Penanggulangan AIDS (KPA). Mengenal Dan Menanggulangi HIV AIDS. KPA Nasional. Jakarta Pusat. 2008

[9] Lempu. 2008. Cegah HIV dengan Strategi Baru. Akses internet di http://lempu.co.cc/index.php/BeritaKesehatan/Cegah-HIV-denganStrategi-Baru.html, 2 Agustus 2009.

[10] Nursalam \& Ninuk. 2007. Asuhan Keperawatan Pada Pasien Terinfeksi HIV/AIDS. Jakarta : Salemba Medika.

[11] Sulianti. 2007. Pemeriksaan Diagnostik HIV/AIDS. Akses internet di http://www.aidsrspiss.com/articles.php?lng=in\&pg= 305, 1 Agustus 2009.

[12] WHO. 2009. Guidance On Testing and Counselling For HIV In Settings Attended By People Who Inject Drugs. Akses Internet di http://www.wpro.who.int/NR/rdonl yres/D243AA59-5C7A-4C0DAF554276E8DB62C7/0/GuidanceonTCin IDUsettings.pdf, 24 Juli 2009.

[13] WHO. 2007. Guidance On Provider-Initiated HIV Testing and Counseling In Health Facilities. Akses internet di http:/aidsina.org/modules.php? name $=$ BookCa talog\&op=showbook\&bid $=40, \quad 26$ Juli 2009.

[14] WHO. 2007. Integrating HIV Voluntary Counselling and Testing Services Into Reproductive Health Setting. Akses internet di http://www.who.int/entity/hiv/pub/v ct/pitc/en/index.html, 24 Juli 2009
[15] WHO. 2009. Priority Interventions, HIV/AIDS Prevention, Treatment, and Care In Health Sector. Akses internet di http://www.who.int/entity/hiv/pub/p riority_interventions_web.pdf, 26 Juli 2009.

[16] WHO. 2009. Terminology Between HIV Counselling and Testing. http://www.who.int/hiv/topics/vct/to olkit/introduction/en/index1.html, 26 Juli 2009. 